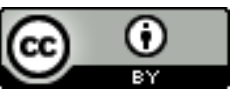

KATSAUKSET JA NÄKÖKULMAT

Maiju Wuokko

\title{
Yhteiskunnallisen kehityksen johtavat voimat
}

\begin{abstract}
ABSTRAKTI / ABSTRACT
Helsingin yliopiston historian oppiaineessa alkoi sylesyllä 2019 unsi perinne, vuosittainen Eino Jutikkala -luento. Ensimmäinen luento järjestettiin tiistaina 12.11.2019 ja pubujana oli FT Maiju Wuokko, joka on tutkinut erityisesti talouden politiikan välisiä kytköksiä 1900-luvun Suomessa. Ennen ja nyt julkaisee Wuokon luentotekstin "Yhteiskunnallisen kebitykesen jobtavat voimat". Syksyisin järjestettävän luennon tarkoituksena on muistuttaa Akateemikeko Eino Jutik.kalan (1907-2006) ja yleisemminkin aiempien bistorioitsijasukupolvien laajasta elämäntyöstä ja tuoda esïn nykeyisten, eri uravaibeissa olevien tutkijoiden työtä historian parissa. Pubujaksi pyydetään vuoroin nuori väitellyt tutkija, vanhempi tutkija ja kansainvälinen tutkija. Sykssyllä 2020 luennon pitää Oklahoman valtionyliopiston professori, historioitsija Jason Lavery.
\end{abstract}

Eino Jutikkala, yrityshistoria, liike-elämä, työmarkkinahistoria, työnantajat, kapitalismi

Maiju Wuokko, FT, poliittisen historian yliopisto-opettaja, Turun yliopisto, maiju.wuokko@utu.fi 


\section{Eino ja minä}

Arvon professorit, hyvät yliopistolaiset ja arvoisa yleisö:

Olen saanut kunnian aloittaa Helsingin yliopiston historian oppiaineen uuden perinteen: jokavuotiseksi suunnitellun Eino Jutikkala -luentojen sarjan. Haluan kiittää tilaisuudesta ja pyrin parhaani mukaan käynnistämään perinteen sen ansaitsemalla tavalla.

Aloitan avaamalla omia kytköksiäni Jutikkalaan ja hänen tutkimukseensa. Ensi ajattelemalta suhdettani Eino Jutikkalaan luonnehtii vain yksi sana: se on oikeastaan olematon. Läheisin linkki lienee jatkoopintojen aikainen työhuonekaverini Petteri Norring, joka käsittelee väitöskirjassaan Eino Jutikkalaa. ${ }^{1}$ Yritän lohduttautua ajatuksella, että katkosten huomaaminen on historiantutkimuksessa aivan yhtä tärkeää kuin jatkuvuuksien hahmottaminen.



Järjestyksessään ensimmäistä Eino Jutikekala -jublaluentoa seurasi runsas kuulijakunta.

Kuva: Anu Labtinen.

Tätä luentoa valmistellessani perehdyin kuitenkin akateemikko Jutikkalaan ja hänen elämäntyöhönsä. Yritin etsiä yhtymäkohtia taustoissamme, tutkimusotteissamme tai tutkimuskohteissamme. Alkuun etsintä paljasti pelkkiä eroavuuksia.

Ensinnäkin tausta: Eino Jutikkala tuli vauraasta talonpoikaisperheestä, joka asutti ja viljeli mahtavaa Jutikkalan kartanoa Hämeen Sääksmäellä. Oma taustani taas juontaa sekalaisten töiden varassa eläneeseen rintamamiestaloon pikkupaikkakunnalla Oulun seudulla. Isäni teki sieltä suurille ikäluokille tyypillisen luokkaretken koulunkäynnin kautta yrittäjäksi ja espoolaislähiön asukkaaksi.

Kuvausten mukaan Eino Jutikkala oli ihmelapsi, jolla oli erinomainen muisti, suuri kiinnostus numeroihin ja fantastinen päässälaskukyky. Omasta muististani en osaa sanoa, mutta valitettavasti en ole koskaan kokenut suurta vetoa numeroihin - kirjoihin, lukemiseen ja kirjoittamiseen kylläkin. Tämä harmillinen numeroiden vieroksuntani ohjasi minut alun perin humanistisen historian pariin, vaikka sittemmin olen profiloitunut laajassa mielessä ymmärretyn taloushistorian tutkijaksi.

Toiseksi, mitä tulee opintojen etenemiseen: Jutikkala pääsi ylioppilaaksi vuonna 1926 ja väitteli tohtoriksi 1932, eli vain kuusi vuotta myöhemmin ja vain 24:n vanhana. Jutikkalalla on edelleen hallussaan 
historiasta väitelleiden nuoruusennätys Helsingin yliopistossa. Hänellä kesti vain kolme vuotta saada väitöskirjansa valmiiksi, ja sama tahti jatkui koko uran ajan. Jutikkala odotti samaa vauhtia myös muilta, mistä hyvästä hän sai opiskelijoiltaan lempinimen Hoppu-Eikka. Minulla taas pelkässä maisterintutkinnossa meni saman verran kuin Jutikkalalla ylioppilaasta tohtoriksi, eikä väitöskirjakaan valmistunut ihan niin jouhevasti kuin olisin aikanaan suonut.

Nämä taustaan ja taipumuksiin liittyvät erot ovat tietysti melko pintapuolisia. Minun ja Jutikkalan välillä vaikuttaa silti olevan syvällisempikin ero. Kuten Helsingin Sanomissa julkaistu muistokirjoitus kertoo, Eino Jutikkalan tutkimustyön ytimessä olivat "koti, suku, maaseudun elinkeinot ja paikallishistoria". Kansallisbiografiassa Päiviö Tommila puolestaan kiteyttää Jutikkalan työn tilastolliseksi ja kartografiseksi väestöhistoriaksi. ${ }^{3}$

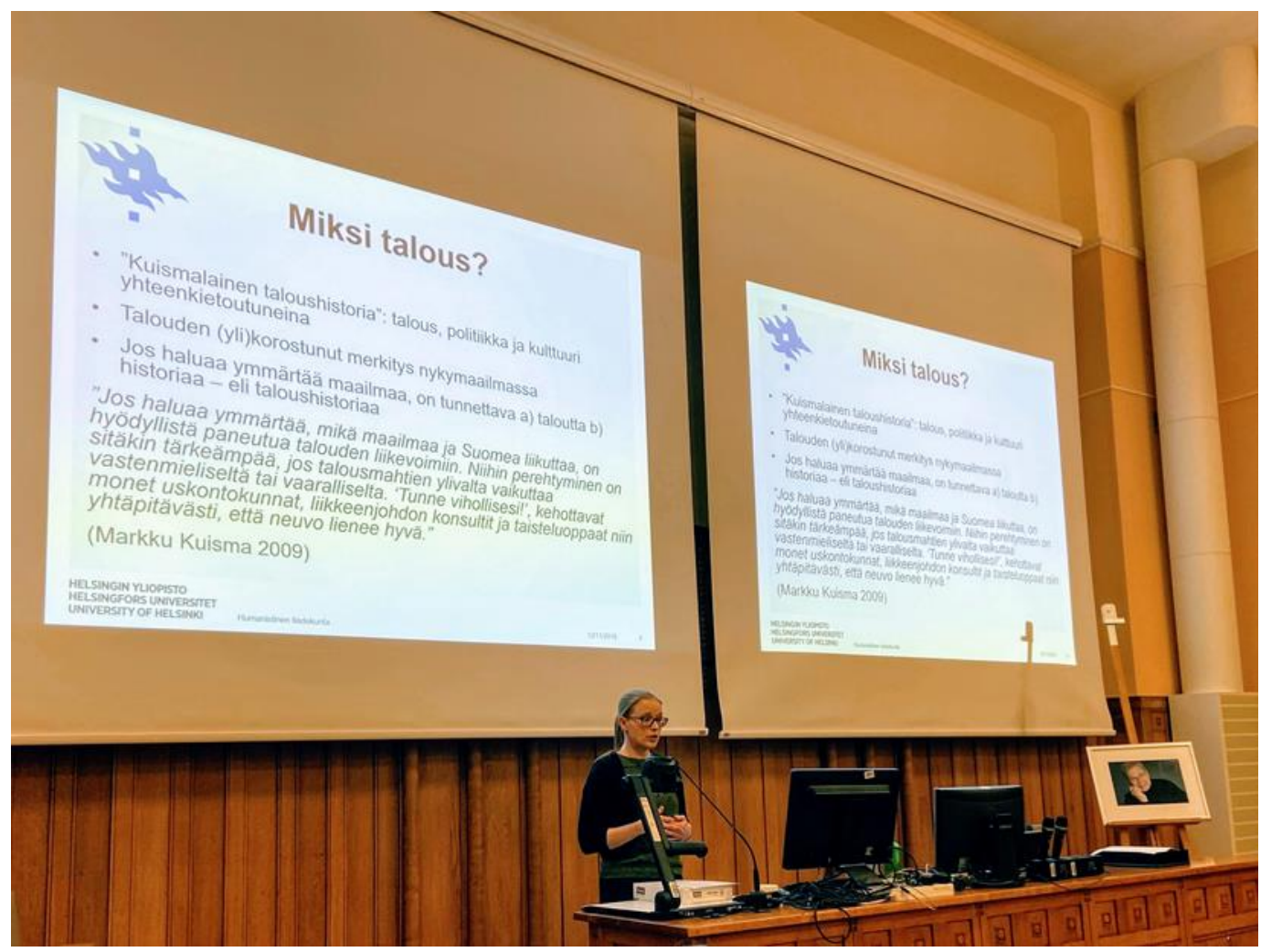

Jublaluennossa Maiju Wuokko käsitteli taloushistorian merkitystä ja esitteli poliittisen taloushistorian ajatusta. Kuva: Mirkka Lappalainen.

Kaiken kaikkiaan Jutikkala edusti kollektiivista ajattelutapaa, jonka mukaan historiaa eivät vie eteenpäin suurmiehet ja poliittiset päätökset, vaan yhteiskunnan sosiaalisissa ja kulttuurisissa rakenteissa tapahtuvat muutokset. Niinpä hän kirjoitti vuonna 1934:

"Historiallisen kehitykesen jobtavat voimat eivät ole löydettävissä kabinettien juonitteluista, hallitusten kirjeenvaibdoista ja valtiopäivien äänestyksistä, vaan ensi sijassa massoissa ilmenevistä valtavista ja lainalaisista muntoksista."

Entäpä sitten oma tutkimukseni? Se on keskittynyt nimenomaan kabinettijuonitteluihin, kirjeenvaihtoon (ja pöytäkirja-aineistoihin) sekä poliittiseen päätöksentekoon ja siihen vaikuttamiseen - voisi siis sanoa, että täysin päinvastaiseen näkökulmaan kuin Jutikkala.

Paradoksaalista kyllä, tämän samaisen Jutikkala-sitaatin avulla löysin lopulta myös yhteyden välillemme. Jutikkala näki yhteiskuntakehitystä liikuttavat voimat massojen liikkeissä. Aivan erityisen merkittävänä suomalaisen yhteiskunnan kehitykselle hän piti maata omistavaa talonpoikaistoa. 
Olen Jutikkalan tapaan kiinnostunut yhteiskuntakehitystä liikuttavista voimista. Tietenkin se, mikä kussakin ajassa ja kullekin tutkijalle näyttäytyy tärkeimmältä huomion kohteelta, vaihtelee. Kun olen suunnannut huomioni yhteiskuntakehityksen johtaviin voimiin, katseeni on Jutikkalan talonpoikien sijaan kohdistunut toisaalle. - Siitä kohta tarkemmin.

\section{Raha ja valta, yritykset ja politiikka}

Toinen yhdistävä tekijä minun ja Eino Jutikkalan välillä on se valtava vaikutus, joka opettajillamme on ollut omaan ajatteluun ja tutkimuskohteiden valintaan. Juuri opettajien kautta myös tähän luentooni saadaan mukaan historian jatkuvuudet: eli, se suunnaton merkitys, joka piilee ajattelu- ja lähestymistapojen periytymisessä opettajilta opiskelijoille ja siten aina uusille tutkijapolville.

Jutikkalalle tärkein opettaja oli Suomen ja Skandinavian historian professori Gunnar Suolahti, joka tutustutti Jutikkalan kollektiivisia ilmiöitä painottavaan tutkimusotteeseen. Omista opettajistani moni istuu tänään yleisössä, ja olen heiltä kaikilta oppinut äärettömän paljon. Kaikkein ratkaisevin merkitys omalle tutkijanuralleni on kuitenkin ollut professori Markku Kuismalla, jonka valokuva sattumoisin juuri tänään paljastettiin. Häneen on helppo soveltaa sanoja, joilla Jutikkala luonnehti omaa opettajaansa Gunnar Suolahtea: "Hän kykenee löytämään totuudelle kauniin ilmaisun. Hänellä on se suuren tyylin lahja, joka pohjautuu suureen persoonallisuuteen." 5

Samaan tapaan kuin Gunnar Suolahti johdatti Jutikkalan kollektiivisten ilmiöiden äärelle, juuri Markku Kuisma avasi omat tutkijansilmäni talouden tärkeydelle sekä rahan ja vallan teemojen yhteen kietoutumiselle.

Edustankin omassa tutkimuksessani taloushistoriaa kuismalaisittain laajasti käsitettynä ja poliittisen taloushistorian hengessä, en niinkään siinä merkityksessä kuin kliometrinen taloushistoria, joka tulee hyvin lähelle taloustiedettä. "Kuismalainen koulukunta" lähestyy taloutta ihmis- ja yhteiskuntatieteellisellä otteella. Sen ydinajatuksena on, että talous, politiikka ja kulttuuri eivät koskaan ole toisistaan erillisiä vaan vaikuttavat koko ajan toinen toisiinsa.

Ihmisten välisenä vaihdannan ja vuorovaikutuksen keinona talous on tietysti ikivanha ilmiö. $\mathrm{Ny}-$ kymaailmassa talouden voimien ja talouselämän toimijoiden merkitys on kuitenkin ratkaisevalla tavalla voimistunut. Talousnäkökohdat ohjaavat niin yksittäisten ihmisten kuin yhteiskuntien toimintaa ja ajattelua; markkinalogiikka on levittäytynyt kulttuuriinkin; ja politiikassa on nykyään pakottavalla tavalla kyse talouden hoidosta ja taloudellisiin välttämättömyyksiin taipumisesta eikä aatteiden ja ihanteiden ajamisesta. ${ }^{6}$

Jos siis haluaa ymmärtää nykypäivän maailmaa, on välttämätöntä ottaa huomioon talous ja sen merkitys. ${ }^{7} \mathrm{Ja}$ jos ajatellaan, että historian tuntemus on välttämätöntä nykyhetken ymmärtämiseksi, ajatuksen voi laajentaa taloushistoriaan: on tunnettava taloushistoriaa, jotta voi ymmärtää nykyhetken taloutta ja sitä kautta koko nykymaailmaa.

Tässä kohtaa haluan tähdentää, että talouden voimien ja toimijoiden ymmärtämisen ei tarvitse tarkoittaa talouden ylivallan hyväksymistä - pikemmin päinvastoin. Markku Kuismaa siteeraten: talouden voimiin "perehtyminen on sitäkin tärkeämpää, jos talousmahtien ylivalta vaikuttaa vastenmieliseltä tai vaaralliselta". Erityisesti silloin kannattaa ohjenuoraksi ottaa viisaus "tunne vihollisesi". 8

Hakeuduin itse rahan ja vallan kysymysten äärelle juuri tällaisesta kriittisestä lähtöasenteesta käsin. Päädyin tutkimaan sitä, miksi ja millä keinoin talouselämä pyrkii vaikuttamaan poliittiseen päätöksentekoon, jotta voisin tehdä tätä vaikutusta näkyväksi ja kohdistaa siihen tarvittaessa kritiikkiä. 
Tässä tuleekin vinkki kaikille omaa tutkimusaihetta etsiville opiskelijoille: kun tutkii sellaista toimijaa, jota ei lähtökohtaisesti sympatiseeraa, kriittisen tutkijanotteen omaksuminen ja ylläpitäminen on huomattavasti helpompaa kuin silloin, kun tutkii kohdetta joka on tullut kaltoin kohdelluksi ja ansaitsee tutkijan mielestä osakseen suurempaa arvostusta ja parempaa näkyvyyttä.

Olen tosin sitä mieltä, että yritysjohtajat, yritykset ja niiden etujärjestöt ansaitsevat tutkijoiden huomion. Ei siksi, että liike-elämä olisi jäänyt osattomaksi vallasta ja vaikuttamismahdollisuuksista, vaan päinvastoin siksi, että sillä niitä on, ehkä enemmän kuin millään muulla eturyhmällä.

Yhdysvaltalaiset yrityshistorian tutkijat Kim Phillips-Fein ja Julian Zelizer ovat tulkinneet, että aiemmilla tutkijapolvilla on kenties ollut tapana lähestyä talouden ja politiikan tematiikkaa ammattiyhdistysliikkeen tutkimisen kautta. Nuorempi tutkijakunta on heidän mukaansa ottanut tarkastelunsa kohteeksi ennemmin liike-elämän, koska juuri se vaikuttaa nykyhetkessä määräävän yhteiskuntakehitystä vastavoimiaan vahvemmin. ${ }^{9}$

Virinneestä kiinnostuksesta huolimatta liike-elämän poliittista vaikutusvaltaa tai rahan ja vallan kytköksiä ei ole alkuunkaan tyhjentävästi käsitelty sen enempää historiantutkimuksessa kuin muilla tutkimusaloilla. Tutkimuksen tarve on sitäkin silmiinpistävämpi, kun otetaan huomioon liike-elämän käytettävissä olevat merkittävät valtaresurssit ja vaikutusmahdollisuudet.

Edellä mainitut yhdysvaltalaistutkijat ovat kirjoittaneet siitä, miten Yhdysvalloissa talouden ja politiikan suhteet ovat jääneet historiantutkimuksen katveeseen: yrityshistorioitsijat ovat keskittyneet kapeammin pelkkään yritysnäkökulmaan, ja perinteiset historiantutkijat ovat tarkastelleet ennemmin sosiaalisia ja kulttuurisia ilmiöitä kuin taloutta. Markku Kuisma on puolestaan esittänyt 1990-luvun alussa kärjistyksen yrittäjistä ja koko yritysmaailmasta suomalaisen historiankirjoituksen marginaaliryhmänä. ${ }^{10}$

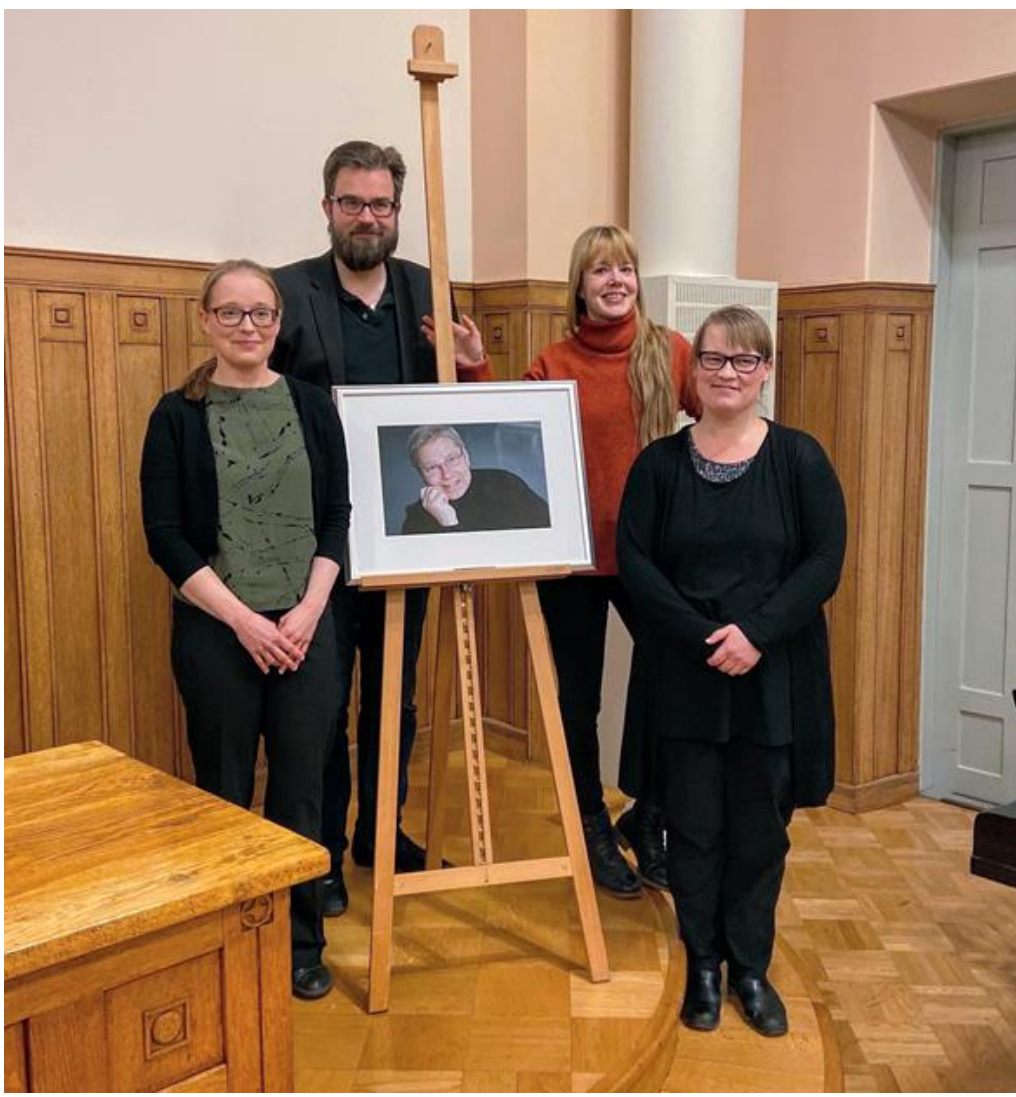

Jublaluennon ybteydessä paljastettiin emeritusprofessori Mark.ku Kuisman muotokuva. Kuvassa (vasemmalta) Maiju Wuokko, Niklas Jensen-Eriksen, Mirkeka Lappalainen ja Anu Labtinen. Kuva: Mirkeka Lappalainen. 
Tilanne on sittemmin alkanut korjaantua niin Suomessa kuin kansainvälisesti katsoen. Siltikin liike-elämän poliittisessa, yhteiskunnallisessa ja kulttuurisessa roolissa on vielä paljon selvitettävää.

Juuri tältä rajapinnalta koen löytäneeni oman paikkani tutkijana. Olen omassa tutkimuksessani keskittynyt erityisesti liike-elämän etujärjestöjen poliittiseen toimintaan ja vaikuttamispyrkimyksiin. Seuraavissa osioissa kerron tarkemmin käsittelemistäni tutkimusteemoista ja ajankohtaisista keskusteluista, joihin ne liittyvät.

\section{Kolmikantakorporatismi}

Viimeisin tutkimushankkeeni on vienyt minut työmarkkinahistorian pariin yhdessä kollegoideni Niklas Jensen-Eriksenin, Elina Kuorelahden, Aaro Saharin ja Henrik Talan kanssa. Kartoitimme Pitkät kihlajaiset -nimisessä hankkeessa Suomen keskitetyn, kolmikantaisen työmarkkinajärjestelmän muotoutumista ja kehitystä.

Hankkeen lopputuloksena syntynyt kirja "Loputtomat kihlajaiset" on parhaillaan taitossa ja ilmestyy tammikuussa 2020. ${ }^{11}$ Kirja kokoaa yksiin kansiin vastaukset liutaan kysymyksiä, kuten: Miksi ay-jäsenmaksut ovat verovapaita ja työnantaja perii ne suoraan palkasta? Mistä on peräisin lomaraha eli ylimääräinen puolen kuun palkka, jonka suurin osa suomalaisista saa joka kesä? Kuka päättää siitä, milloin Suomessa saa jäädä eläkkeelle? Mikä vaikutus työmarkkinajärjestöillä on ollut suomalaisen hyvinvointivaltion muotoiluun ja sen kustannusten jakamiseen? Entä miksi työmarkkinajärjestöillä on parlamentaarisessa demokratiassa niin paljon valtaa - miksi mitään laajaa talous- tai sosiaalipoliittista ratkaisua ei saada aikaan ilman kolmikantaista valmistelua?

Kirjan nimi viittaa tietysti legendaariseen tammikuun kihlaukseen, joka on suomalaisen työmarkkinahistorian virstanpylväs. Kihlaus oli työntekijä- ja työnantajapuolen keskusjärjestöjen keskellä talvisotaa antama julkilausuma, jossa ne tunnustivat toisensa neuvottelukumppaneiksi. Ei kuulosta paljolta eikä oikeastaan ollutkaan, mutta tästä alkoi pitkällinen ja polveileva kehitys kohti tupo-Suomea, jossa ammattiyhdistysliikkeen, työnantajien ja valtion kolmikanta päätti keskitetysti niin palkoista ja työehdoista, talouspolitiikan raameista, verotuksesta, sosiaalietuuksista kuin työ- ja vapaa-ajasta.

Olemme tutkimushankkeessa keskittyneet nimenomaan työnantajapuoleen ja sen etujärjestöön Suomen Työnantajain Keskusliittoon sekä sen seuraajiin, Teollisuuden ja Työnantajain Keskusliittoon ja nykyiseen Elinkeinoelämän Keskusliittoon. Koska ne eivät tietenkään ole koskaan toimineet tyhï̈ssä, tulemme samalla käsitelleeksi liike-elämän muita järjestöjä, kuten palvelualan työnantajia ja yrittäjäjärjestöjä, mutta myös palkansaajapuolen järjestöjä ja poliittisia päättäjiä.

Keskittyminen työnantajiin on perusteltua, koska työnantajia on tutkittu vähemmän kuin palkansaajapuolta ja erityisesti sen suurinta ja vahvinta järjestöä SAK:ta. Sitä paitsi työnantajilla on ollut järjestelmän muotoutumisessa aivan yhtä tärkeä rooli kuin työntekijöillä. Työnantajat eivät ole vain passiivisesti reagoineet ay-liikkeen ja valtiovallan vaatimuksiin. Järjestelmässä mukana olemalla he ovat aktiivisesti edistäneet omia intressejään ja pystyneet torppaamaan tai vähintään vesittämään haitallisiksi ja ei-toivotuiksi kokemiaan uudistuksia. Työnantajat ovat yksinkertaisesti hyötyneet riittävästi pysyäkseen mukana kolmikantaisessa päätöksenteossa. Tämä siitä huolimatta, että työnantajat ovat jo lähes puoli vuosisataa valittaneet, että suomalainen työmarkkinajärjestelmä on liian keskitetty ja työmarkkinapolitiikka on liian jäykkää.

Kihlajaiset ovat kirjan nimen mukaisesti "loputtomat", koska suomalaisten työmarkkinasuhteiden historia on kuin päättymättömät juhlat. Juhlista ei pääse lähtemään, vaikka kuinka yrittäisi. Lisäksi tilaisuus 
on vain kutsuvieraille, ja kutsuvierasjoukon ohella yhtä oleellista on se, keitä ei ole kutsuttu. Juhlien ulkopuolelle on jätetty esimerkiksi kommunistit, naiset, toimihenkilöt ja pienyrittäjät. Toisinaan juhlimisen seurauksena on ollut krapula, joka taittuu vain sillä millä se tulikin eli sinnikkäästi kolmikantajuhlia jatkamalla.

"Tammikuun kihlaus" työmme alkupisteenä sai meidät lähestymään työmarkkinasuhteita parisuhdevertausten kautta. Tarkoituksena on ollut tehdä työmarkkinahistorian perusasetelmat helposti lähestyttäviksi ja ymmärrettäviksi. Tarinamme laaja kaari kertoo, miten sodanaikainen ja -jälkeinen kosiskeluaika muuttui kinastelun sävyttämäksi, arkiseksi liitoksi ja lopulta päättymättömän tuntuiseksi eron tekemiseksi. Hankkeen kuluessa meille on käynyt selväksi, että työmarkkinahistoriassa ei ole mitään puisevaa tai tylsää. Päinvastoin, siinä leimuavat suuret tunteet ja vahvat intohimot: kasassa ovat siis kunnon parisuhde-draaman ainekset.

Tarinaan kuuluu myös paljon värikkäitä yksityiskohtia. On esimerkiksi salainen ovi, josta sosiaalidemokraattiset ay-johtajat pääsivät kommunistien tietämättä Eteläranta 10:n työnantajalinnakkeeseen; yhtä salamyhkäinen "teollisuusovi” oli SAK:n päämajassa Hakaniemessä työnantajajohtajia varten. Työehtosopimusneuvottelut puolestaan näyttäytyvät yökausia kestävinä väsytystaisteluina. Voitto kuului sille, jolla oli vahvimmat istumalihakset ja paras väsymyksen sietokyky. Eteläranta 10:ssä, jonka yläkerrassa toimi legendaarinen Palace-ravintola, epäilemättä nautittiin monenmoisia gourmet-herkkuja, mutta neuvottelupöytien tarjoilu noudatti perinteitä: Janssonin kiusausta siinä vaiheessa, kun neuvottelut jatkuivat; nakkeja ja perunasalaattia, kun loppusuora alkoi häämöttää; ja tietenkin samppanjaa sopimukseen pääsyn kunniaksi.

Anekdootit sikseen; työmarkkinasuhteiden historiaa ei yksinkertaisesti voi sivuuttaa, jos haluaa ymmärtää, miten Suomesta tuli se Suomi, jossa nyt elämme.

Tutkimusryhmämme tulkinta pähkinänkuoressa on, että toisen maailmansodan jälkeisistä vuosista aina 1970-luvulle asti työnantajat torjuivat keskitetyn työmarkkinapolitiikan avulla kommunismin uhkaa ja ostivat yhteiskuntarauhaa. Vasemmistovaara väistyi 1980-luvulla, ja siitä lähtien työnantajat ovat koko ajan kärjekkäämmin arvostelleet keskitettyä järjestelmää. Arvostelusta huolimatta työnantajat ovat vuosikymmenestä toiseen päätyneet solmimaan keskitettyjä sopimuksia käytännön syistä ja parempien vaihtoehtojen puutteessa. Keväällä 2017 Elinkeinoelämän Keskusliitto otti peruuttamattoman tuntuisen irtioton: se muutti sääntöjään siten, että ei enää pysty tekemään keskitettyjä sopimuksia palkansaajakeskusjärjestöjen kanssa.

Jos olemme työmarkkinahistoriasta jotain oppineet, se on kuitenkin tämä: keskitetty järjestelmä on säilynyt hämmästyttävän sitkeästi läpi monenlaisten yhteiskunnallisten murrosten, poliittisten virtausten ja taloussuhdanteiden heilahtelun. Niinpä tuntuu nytkin ennenaikaiselta julistaa Suomen keskitetyn työmarkkinamallin loppua. Sääntöjähän voi ensinnäkin aina muuttaa; ja on myös tärkeää huomata, että vaikka keskitettyjä työehtosopimuksia ei enää tehtäisikään, kolmikanta ei ole kuolemassa mihinkään. Työmarkkinajärjestöt ovat edelleen mukana lukuisissa kolmikantaisissa työryhmissä valmistelemassa ja tekemässä meidän kaikkien elämään vaikuttavia päätöksiä.

Työmarkkinasuhteiden historiasta kulkee suora yhteys tämän hetken yhteiskunnalliseen keskusteluun. Vuodenvaihteen molemmin puolin monen alan työehtosopimukset ovat päättymässä, ja parhaillaan neuvotellaan uusista sopimuksista. Neuvottelut nostavat pintaan näkemyseroja esimerkiksi niin kutsuttujen kiky-tuntien jatkamisesta, paikallisen sopimisen laajentamisesta tai naisvaltaisen hoitoalan palkankorotusvaatimuksista. Ajankohtaisuudestaan huolimatta kiistoilla on pitkät juurensa, joita työmarkkinahistoria auttaa valaisemaan. 


\section{Markkinatalouden puolustus}

Omista tutkimusaiheistani on suora kytkös myös toiseen ajankohtaiseen keskusteluun. Syyskuussa brittiläinen talousalan sanomalehti Financial Times vaati näkyvästi markkinatalousjärjestelmän "resetointia" eli uudelleen määrittelyä. Päätoimittaja Lionel Barberin mukaan vapaaseen kilpailuun perustuva markkinatalous ei enää toimi. Järjestelmää olisi muokattava niin, että osakkeenomistajien edun lisäksi yritykset tavoittelisivat työntekijöidensä ja asiakkaidensa etua ja yleistä hyvää. ${ }^{12}$

Kuukautta aiemmin Yhdysvaltain suurimpia yrityksiä edustava Business Rountable julkisti uuden periaatelinjauksensa. Järjestö on perinteisesti korostanut, että yritysten on ensisijaisesti palveltava osakkeenomistajien etua. Uusi linjanveto korostaa myös muiden sidosryhmien etua ja yritysten yhteiskunnallista vastuuta. ${ }^{13}$

Vastuunkannon ja uudistumisen vaatimukset eivät kuitenkaan murenna Financial Timesin ja Business Roundtablen vahvaa sitoutumista markkinatalouteen: molemmat korostavat edelleen, että vapaa markkinatalous on paras perusta työpaikkojen, innovaatioiden, verovarojen ja yleisen hyvinvoinnin luomiselle.

Ensi ajattelemalta ulostulot saattavat joka tapauksessa vaikuttaa poikkeuksellisilta, peräti mullistavilta. Historiantutkijan korviin ne kuulostavat silti perin tutuilta. Yhtymäkohdat 1970-luvun keskusteluihin ovat hämmästyttävän ilmeisiä. Juuri tuolloin Suomeen rantautui ensi kertaa ajatus yritysten yhteiskuntavastuusta.

1970-luvun vaihteessa yhteiskunnallinen ilmapiiri länsimaissa, Suomi mukaan lukien, oli vahvasti vasemmalle kallellaan. Oikeisto- ja yrityspiirit pelkäsivät jopa vasemmistolaista vallankumousta. Lievemmässä muodossa huolenaiheena olivat lainsäädännöllä etenevä, hiipivä sosialismi ja yksityisyritysten kansallistamiset. Suomalaiset yritysjohtajat eivät olleet pelkoineen yksin, vaan samanlaisia kauhuskenaarioita elättelivät heidän ruotsalaiset, brittiläiset ja jopa yhdysvaltalaiset kollegansa. ${ }^{14}$

Pelot olivat ylimitoitettuja, mutta todellisuudessakin aikakautta leimasivat vasemmistovirtaus, kiristyvä verotus, kasvavat hyvinvointimenot, laajamittainen lakkoilu, ja talouden sääntely - eli "säännöstelymentaliteetti ja poikkeuslakihysteria", kuten teollisuusvaikuttaja Gay Ehrnrooth totesi vuonna $1976 .{ }^{15}$

Liike-elämä ryhmittyi taisteluun vaaralliseksi kokemiaan poliittisia ja yhteiskunnallisia virtauksia vastaan. Niin Suomessa kuin muualla lännessä puolustustaistelu kanavoitui liike-elämän etujärjestöjen kautta: vanhoja järjestöjä elvytettiin ja uusia perustettiin. Suomessa osana tätä 1970-luvun aaltoa perustettiin Elinkeinoelämän Valtuuskunta (EVA) ja Teollisuuden Keskusliitto (TKL).

EVA:n ja TKL:n pyrkimyksenä oli tehostaa yritys- ja markkinamyönteistä ajattelua yhteiskunnassa ja politiikassa. Tavoitteen toteuttamiseksi järjestöt sekä lobbasivat poliittisia päättäjiä että vaikuttivat yleiseen mielipiteeseen. Oletetut vallankumous- tai sosialisointiaikeet pyrittiin kumoamaan valistustoiminnalla, joka alleviivasi yritystoiminnan merkitystä koko kansakunnan vauraudelle ja hyvinvoinnille.

EVA ja TKL korostivat, että sosiaaliturvaa, kulttuuripalveluita ja ympäristönsuojelua voitiin kehittää vain yritysten voitoista perittävien verojen turvin. TKL:n toimitusjohtaja Stig Hästö totesikin, että "Olisi saatava 'perille' se sanoma, että vain voittoa tuottava kannattava yritys voi olla kilpailukykyinen, suorittaa investointeja, taata turvallisen työpaikan ja olla palkanmaksukykyinen."16

EVA:n mukaan yritysten täytyi silti kantaa sosiaalinen vastuunsa ja ottaa huomioon eri sidosryhmien edut. EVA:n toimitusjohtaja Max Jakobson ehdotti, että yritykset voisivat tuoda myönteistä yhteiskunnallista panostaan esille sosiaalisten tilinpäätösten avulla. Ne olivat aikakauden kansainvälinen uutuus, joilla havainnollistettiin yritystoiminnan yhteiskunnallisia vaikutuksia tulostaseen rinnalla. Tarkoituksena 
oli kiinnittää huomiota yritysten sosiaaliseen vastuuntuntoon ja hillitä yritystoimintaan kohdistettua arvostelua.

Perustehtävänsä mukaisesti Elinkeinoelämän Valtuuskunta korosti markkinatalouden yhteen kietoutumista länsimaisen demokratian ja moniarvoisen yhteiskunnan kanssa. Samalla toimitusjohtaja Jakobson painotti, että oli hyväksyttävä myös markkinatalousjärjestelmän uudistamisen tarve; yritysystävällisyys ja uudistusmyönteisyys eivät saaneet olla toisilleen vastakkaisia.

Uudistusvalmius ei tarkoittanut passiivista alistumista poliittisen vasemmiston reformivaatimuksiin. Aloitetta ei missään tapauksessa saanut luovuttaa vasemmiston käsiin. Evalainen uudistusvalmius merkitsi päinvastoin liike-elämän aktiivista yhteiskuntapoliittista roolia. Taustalla vaikutti ajatus, että ainoastaan osallistumalla uudistusten sisältöön voitaisiin vaikuttaa. Uudistusten kustannukset kenties rasittaisivat yritysten "lyhyen tähtäyksen kannattavuutta", mutta niiden vastustaminen voisi johtaa "poliittisiin tappioihin, jotka myöhemmin maksetaan taloudellisesti". ${ }^{17}$

Juuri poliittisten tappioiden pelko yhdistää 1970-luvun ja nykypäivän. Toimitusjohtaja Ehrnrooth tuskaili puoli vuosisataa sitten, miten teollisuutta syytettiin saastuttamisesta, resurssien tuhlaamisesta ja kuluttajien pakottamisesta ostamaan tuotteita, joita he eivät tarvitse. Ilmastoahdistuneessa ajassamme, jossa ympäristönäkökohdat haastavat yhä vakavammin taloudelliset arvot, yritysten edustajat tuntevat olevansa hyvin samankaltaisten syytösten kohteena.

Myös vastaus haasteeseen vaikuttaa identtiseltä. Kuten EVA ja TKL 1970-luvulla, talouselämän toimijat ovat nyt heränneet vaatimaan yritysten yhteiskuntavastuuta ja markkinatalouden uudelleenmäärittelyä. Tutkijana tulkitsen, että olemalla aloitteellisia ja vaatimalla omaehtoisesti markkinatalouden uudistamista yhdysvaltaiset yritysjohtajat ja brittiläinen talouslehti tukeutuvat vain vanhaan viisauteen, jonka mukaan hyökkäys on paras puolustus.

Tavoitekin on sama kuin 1970-luvulla: lievittää yritys- ja markkinakielteisiä asenteita ja ennaltaehkäistä yritystoiminnan sääntelyä, johon valtiot saattaisivat kestävän kehityksen ja ympäristönsuojelun nimissä ryhtyä. Tai, jos toimenpiteitä ei voi kokonaan estää, liike-elämän edustajat haluavat ainakin päästä mukaan päättämään siitä, miten markkinatalous mahdollisesti muuttuu ja millä tavoin sääntely pannaan toimeen.

Analogioita voisi vetää nykyhetkestä paitsi 1970-luvulle, myös 1900-luvun alkuun, jolloin työnantajat alun perin järjestäytyivät vastareaktiona työväenliikkeen "hyökkäykselle" porvarillista yhteiskuntaa $\operatorname{vastaan}^{18}$; tai sotienväliselle kaudelle, jolloin liike-elämä rahoitti kommunismin vastaista konservatiivista propagandaa; tai 1940-luvun lopulle ja -50-luvun alkuun, jolloin liike-elämä taisteli kommunismin uhkaa vastaan; tai 1980-luvulle, jolloin liike-elämän järjestöt tehostivat PR-työtään vastauksena ympäristöliikkeen nousulle, nollakasvuideologialle ja ydinvoimavastaisuudelle.

Reaktio siis toistuu vuosikymmenestä toiseen: vihamielisten tai kriittisten poliittisten vastavoimien edessä liike-elämä ryhmittyy puolustustaisteluun yritystoiminnan ja koko markkinatalouden puolesta. Puolustautumiskeinona on tehostaa järjestöjen mielipidevaikuttamista, joka muun muassa alleviivaa yritysten sosiaalista vastuuta ja positiivista yhteiskunnallista kontribuutiota. ${ }^{19}$

Samoin kuin työmarkkina-asioissa, myös markkinataloudesta käydyssä keskustelussa menneisyyden tunteminen auttaa siis asettamaan ajankohtaisen ilmiön osaksi laajempia yhteyksiään. Historiantuntemus valottaa yllättäviä yhtenevyyksiä eri aikojen välillä; ja kun ilmiö asettuu osaksi pitempää jatkumoa, sen yltä karisee ainutlaatuisuuden taika ja sitä on mahdollista arvioida syvällisemmin. 


\section{Mikä "liike-elämä"?}

Perusteltuani pitkään sitä, miten tärkeää liike-elämän etujärjestöjen historian tutkiminen on ja miksi se on välttämätöntä nyky-yhteiskunnan luonteen ja ajankohtaisen julkisen keskustelun ymmärtämiseksi, haluan vielä ottaa esiin eräitä itsekriittisiä näkökohtia.

Kansainvälisessä etujärjestötutkimuksessa on täysin perustellusti epäilty sitä, onko liike-elämää mielekästä lähestyä sen etujärjestöjä tutkimalla. On myös kyseenalaistettu, voiko "liike-elämästä” ylipäätään puhua yksikössä, yhtenäisenä toimijana. ${ }^{20}$ Tosiasiassahan kyse on yritysjohtajien, yritysten ja paikallisten, alakohtaisten sekä valtakunnallisten järjestöjen muodostamasta kirjavasta kudelmasta. Sen sisällä vallitsee aina taloudellisia eturistiriitoja, poliittisia näkemyseroja ja henkilökemioista johtuvia hankauksia.

Liike-elämän edunvalvontaa rasittaa perustavanlaatuinen ristiriita: yritykset käyvät jatkuvaa kilpailua toistensa kanssa siitä, kenellä on parhaat tuotteet, maksukykyisimmät asiakkaat ja suurimmat markkinaosuudet. Tämä tietysti murentaa ajatusta yhteisestä hyvästä, jota ajaa edunvalvonnan keinoin. Yrittäjät ovat usein voimakastahtoisia ja omanarvontuntoisia persoonallisuuksia, jotka kannattavat liberaaleja arvoja ja yksilönvapautta. Tämäkin sotii kollektiivista järjestäytymistä vastaan. Liberaaleja asenteita lietsoo myös haluttomuus maksaa kuluja, joita järjestöjen pyörittämiseen väistämättä liittyy.

Asenteet kiteyttää teollisuusjohtaja Hugo Rosenlewin kommentti 1900-luvun alusta, jolloin sahateollisuuteen oltiin perustamassa työnantajaliittoa: "... tällainen yhteenliittyminen johtaa yksilön toimintaja märäämisvapauden rajoittumiseen, mikä ei voi vastata hänen ihannettaan”. ${ }^{21}$

Tutkijan on tietysti tunnustettava ja tiedostettava tämä moniäänisyys ja sisäiset ristiriidat liikeelämää tutkiessaan. Yhdessä kollegani Susanna Fellmanin kanssa kartoitamme parhaillaan keinoja tämän moniäänisyyden haasteen hallitsemiseksi, mutta helppoja ratkaisuja ei löydy. Sama haaste liittyy tietysti myös vaikkapa ammattiyhdistysliikkeen, ympäristöliikkeen, tai minkä tahansa poliittisen puolueen tutkimiseen. Nähdäkseni näitä kaikkia on silti mielekästä lähestyä toimijaryhminä, joita pitää kasassa riittävä määrä yhteisiä ihanteita ja intressejä.

Väittäisin jopa, että tutkijoina meillä on vastuu tarkastella liike-elämää eturyhmänä, joka puolustaa ja ajaa omia etujaan. Jos "liike-elämän” tarkastelu yksikössä tuomitaan täysin mahdottomaksi, menetetään samalla näkyvistä sen yhteiskunnallinen vaikutusvalta. Tämä taas olisi kestämätön tilanne, jos ja kun halutaan tehdä yhteiskunnallisesti relevanttia, rehellistä ihmis- ja yhteiskuntatieteellistä tutkimusta. Sellaista edellyttää jo historioitsijan oma tutkijanetiikka, mutta myös Tutkimuseettinen neuvottelukunta TENK, jonka vuoden 2009 ohjeistuksen mukaan "Historiallisen ja yhteiskuntatieteellisen tutkimuksen tärkeä tehtävä on tuottaa tietoa yhteiskunnallisten instituutioiden ja vallankäytön epäkohdista."22

Tässä yhteydessä lainattuna TENKin muotoilu "vallankäytön epäkohdista" saa tietysti ajattelemaan, että liike-elämän poliittisessa toiminnassa olisi lähtökohtaisesti jotain väärää. Tämä on mielestäni ongelmallinen oletus, joten muokkaan lainauksen muotoon: "historiantutkimuksen tärkeä tehtävä on tuottaa tietoa yhteiskunnallisista instituutioista ja vallankäytöstä’. Liike-elämänkin vallasta puhuttaessa täytyy ensin tietää, millaista tämä valta on ja miten sitä käytetään, ennen kuin sen voidaan perustellusti väittää olevan hyvästä tai pahasta - todennäköisimmin tutkija päätyy johonkin siltä väliltä.

On syytä korostaa, että eri eturyhmillä on oikeus perustaa etujärjestöjä ajamaan intressejään politiikassa ja yhteiskunnassa yleensä. Ongelmia tietysti syntyy silloin, jos yhdellä eturyhmällä on huomattavasti isommat voimavarat ja tehokkaammat vaikutuskeinot kuin toisilla. Monien etujärjestötutkijoiden mielestä juuri liike-elämä on tällainen muita paremmin resursoitu ja vahvempi eturyhmä, joten sen vaikuttamista on erityisen perusteltua pitää tutkimuksen keinoin silmällä. 
Media- ja viestintätieteilijät Anu Kantola ja Hanna Kuusi ovat Huipputuloiset-kirjassaan nostaneet esiin huolestuttavan kehityssuunnan, johon yhteiskunnan vauraimpien vaikuttaminen näyttää kulkevan. Heidän mukaansa huipputuloiset suomalaiset ovat menettäneet uskonsa edustuksellisen demokratian toimivuuteen, ja lisäksi heidän uskonsa liike-elämän etujärjestöjen toimintaan on hiipumassa. Niinpä heidän poliittinen vaikuttamisensa on valumassa etujärjestöiltä yksityiseen yhteydenpitoon poliittisten päätäjien kanssa. Huipputuloiset luottavat henkilökohtaisiin verkostoihinsa ja siihen, että poliitikoilla riittää aikaa ja ymmärrystä heidän asialleen aina kun on tarvis. ${ }^{23}$

Historiantutkijana täytyy tietysti taas hieman toppuutella: taloudellisen ja poliittisen eliitin tiiviissä verkostoissa ei tietenkään ole mitään uutta, päinvastoin. Eikä toisaalta ole syytä ajatella, että kaikki etujärjestöjen kautta kanavoituva vaikuttaminen olisi automaattisesti avointa ja asiallista. Järjestön toiminta vain jättää enemmän jälkiä - muistioita, pöytäkirjoja, kirjeenvaihtoa, tiedotteita, lehtijuttuja - kuin yksityishenkilöiden välinen epämuodollinen yhteydenpito. Järjestötason vaikuttamista on helpompi sekä pitää julkisuuden valvovan silmän alla että tulevien historiantutkijoiden aikanaan analysoida kriittisellä otteella.



Tutkimuksessaan Wuokko on keskittynyt erityisesti liike-elämän etujärjestöjen historiaan.

Lopuksi vielä muutama sananen jo useasti mainitsemastani kriittisestä tutkijanotteesta. Helsingin Sanomissa julkaistiin heinäkuun lopussa Markku Kuisman jäähyväishaastattelu hänen jäädessään virallisesti eläkkeelle tehtävistään Suomen ja Pohjoismaiden historian professorina. Haastattelun lopussa 
Kuisma pohtii, onko kenties omalla toiminnallaan onnistunut vahvistamaan nykymaailman markkinauskoa ja "konsulttihöpötystä". ${ }^{24}$

Kuisma kokee, että hänen nuoruudessaan yritystoimintaan suhtauduttiin automaattisen kielteisesti; "siinä oli vaistomaisesti jotain mätää". Kuisman omasta mielestä yritystoiminta on "päinvastoin fiksua ja älykästä”. Eläkkeelle jäädessään hän ei kuitenkaan voinut olla pohtimatta, onko hän ollut tekemässä yritystoimintaa liiankin ihailtavaksi ja ymmärrettäväksi, niin että ihmisten luontainen epäluulo yrityksiä kohtaan on heikentynyt. Tutkijan rautaisella itsevarmuudella tämä Suomen luetuimpiin kuuluva historioitsija tulee kuitenkin siihen tulokseen, että tällainen ajattelu olisi oman vaikutuksen yliarviointia.

Olen omilla kirjoituksillani tavoittanut vasta murto-osan Markku Kuisman saavuttamista yleisöistä, mutta olen jo tullut pohtineeksi samansuuntaisia kysymyksiä. Käykö historiantutkijalle niin, että sen lauluja laulat, jonka lähteitä luet? Miten tutkija voisi tehtävänsä mukaisesti arvioida menneisyyden ilmiötä tai toimijaa, jos ei kunnolla ymmärrä arvioinnin kohdetta? Mutta missä kulkee ymmärrettäväksi tekemisen ja kritiikittömyyden välinen raja?

Oma lähtöasenteeni liike-elämän tutkimiseen on, kuten sanottu, ollut kriittinen. Koen, että asenteeni on kyllä säilynyt, mutta rinnalle on tullut lisäksi ymmärtämystä, arvostustakin. Koko kuvioon on tullut lisää sävyjä. Yrittäjät, yritykset ja niiden yhteenliittymät ansaitsevat mielestäni osakseen saavutustensa ihastelua, hullutustensa taivastelua, ja ihmisten näkemistä talouspuheen takaa. Asia erikseen ovat muka-kiistämättömät talouden tosiasiat ja sokea markkinausko, jotka kaipaavat kritiikkiä ja kyseenalaistamista.

Historiantutkijoina meillä on sekä oikeus että velvollisuus esittää perusteltua arvostelua, kun yhteiskunta näyttää kulkevan arveluttavaan suuntaan. Kritiikin on yhtä kaikki nojattava punnittuun tutkimustietoon, huolelliseen lähdekritiikkiin ja aitoon ymmärtämisen haluun, eikä skandaalinkäryisiin spekulaatioihin rahan ja vallan mahdista.

Pidetään siis huoli, että valveutuneina kansalaisina ja historiantutkijoina pysymme herkkinä sille, mitä yhteiskunnallisen kehityksen johtavat voimat kunakin aikana ovat; mihin suuntaan ne kehitystä ohjaavat; ja kenen etuja kehitys palvelee ja keiden edut ovat kenties vaarassa jäädä kehityksen jalkoihin. 


\section{Kirjallisuus}

Ahtiainen, Pekka \& Jukka Tervonen. Menneisyyden tutkijatja metodien vartijat. Matka suomalaiseen bistoriankirjoitukeeen. Suomen Historiallinen Seura, Helsinki 1996.

Hart, David M. “Business” Is Not an Interest Group. On the Study of Companies in American National Politics. Annual Review of Political Science 7:1 (2004), 47-69. https://doi.org/10.1146/annurev.polisci.7.090803.161829

Kantola, Anu \& Kuusela, Hanna. Huipputuloiset. Suomen rikkain promille. Vastapaino, Tampere 2019.

Kuisma, Markku. Metsäteollisuuden maa. Suomi, metsät ja kansainvälinen järjestelmä 1620-1920. Suomen Historiallinen Seura, Helsinki 1993.

Kuisma, Markku. Suomen poliittinen taloushistoria 1000-2000. Toinen, uudistettu painos. Siltala, Helsinki 2013.

Mansner Markku. Suomalaista ybteiskuntaa rakentamassa. Suomen Työnantajain Keskusliitto 1907-1940. Teollisuuden Kustannus Oy, Helsinki 1981.

Mansner, Markku. Suomalaista ybteiskuntaa rakentamassa. Suomen Työnantajain Keskusliitto 1980-1992. Helsinki: Elinkeinoelämän Keskusliitto, 2005.

Norring, Petteri. Eli F. Heckscher, Eino Jutikkala ja pohjoismainen ybteiskuntahistoria. Helsingin yliopisto, Helsinki 2018. http://urn.fi/URN:ISBN:978-951-51-4287-0

Phillips-Fein, Kim \& Julian E. Zelizer. Introduction. Teoksessa Kim Phillips-Fein \& Julian E. Zelizer (toim.) What's Good for Business. Business and American Politics Since World War II. Oxford University Press, Oxford - New York 2012, 3-15.

Tommila, Päiviö. Jutikkala, Eino. Kansallisbiografia-verkkeojulkaisu. Studia Biographica 4. Suomalaisen Kirjallisuuden Seura, Helsinki 2015. http://urn.fi/urn:nbn:fi:sks-kbg-007054

Wuokko, Maiju. Markkinatalouden etujoukot. Elinkeinoelämän valtuuskunta, Teollisunden keskusliitto ja liike-elämän poliittinen toiminta 1970-1980-lukujen Suomessa. Helsingin yliopisto, Helsinki 2016. http://urn.fi/URN:ISBN:978-951-51-2456-2

Wuokko, Maiju. Business in the battle of ideas, 1945-1991. Conclusions from the Finnish case. Scandinavian Economic History Review 65:3 (2017), 279-293. https://doi.org/10.1080/03585522.2017.1371638

Wuokko, Maiju, Jensen-Eriksen, Niklas, Tala, Henrik, Kuorelahti, Elina \& Sahari, Aaro. Loputtomat kihlajaiset. Yritykeset ja kolmikantakorporatismi Suomessa 1940-2020. Siltala, Helsinki 2020. 


\section{Verkkolähteet}

Business Roundtable 19.8.2019. Business Roundtable Redefines the Purpose of a Corporation to Promote 'An Economy That Serves All Americans'. https://www.businessroundtable.org/business-roundtable-redefines-thepurpose-of-a-corporation-to-promote-an-economy-that-serves-all-americans (luettu 19.10.2020).

Financial Times 18.9.2019. The New Agenda. https://aboutus.ft.com/en-gb/new-agenda/ (luettu 5.11.2019).

Helsingin Sanomat 22.12.2006. Jukka-Pekka Lappalainen. Eino Jutikkala. https://www.hs.fi/muistot/art2000002627096.html (luettu 19.10.2020).

Helsingin Sanomat 29.7.2018. Esa Lilja. Viimeinen luento. https://www.hs.fi/sunnuntai/art2000005771302.html (luettu 19.10.2020).

Humanistisen, yhteiskuntatieteellisen ja käyttäytymistieteellisen tutkimuksen eettiset periaatteet ja ehdotus eettisen ennakkoarvioinnin järjestämiseksi. Tutkimuseettinen neuvottelukunta, Helsinki 2009. https://tenk.fi/fi/ohjeet-jaaineistot (luettu 19.10.2020). 


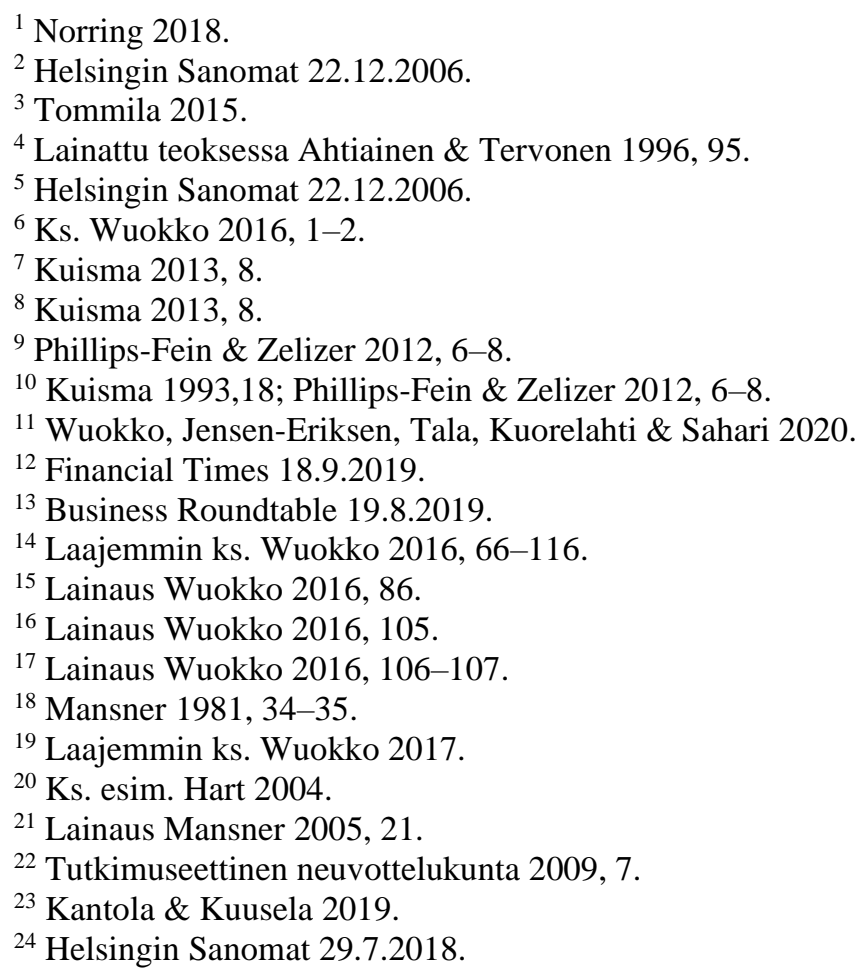

